\title{
Developing transgenic wheat to encounter rusts and powdery mildew by overexpressing barley chi26 gene for fungal resistance
}

Hala F. Eissa ${ }^{1,2^{*}}$, Sameh E. Hassanien ${ }^{1}$, Ahmed M. Ramadan 1,3, Moustafa M. El-Shamy ${ }^{4}$, Osama M. Saleh ${ }^{5,6}$, Ahmed M. Shokry ${ }^{1}$, Mohamed Abdelsattar ${ }^{1}$, Yasser B. Morsy ${ }^{1}$, Maher A. El-Maghraby ${ }^{7}$, Hussien F. Alameldin ${ }^{1,8}$, Sabah M. Hassan ${ }^{3,9}$, Gamal H. Osman 1,10*, Hesham T. Mahfouz ${ }^{11}$, Gharib A. Gad El-Karim', Magdy A. Madkour ${ }^{12}$ and Ahmed Bahieldin $3,9^{*}$

\begin{abstract}
Background: The main aim of this study was to improve fungal resistance in bread wheat via transgenesis. Transgenic wheat plants harboring barley chitinase (chi26) gene, driven by maize ubi promoter, were obtained using biolistic bombardment, whereas the herbicide resistance gene, bar, driven by the CaMV 355 promoter was used as a selectable marker.

Results: Molecular analysis confirmed the integration, copy number, and the level of expression of the chi26 gene in four independent transgenic events. Chitinase enzyme activity was detected using a standard enzymatic assay. The expression levels of chi26 gene in the different transgenic lines, compared to their respective controls, were determined using qRT-PCR. The transgene was silenced in some transgenic families across generations. Gene silencing in the present study seemed to be random and irreversible. The homozygous transgenic plants of T4, T5, T6, T8, and T9 generations were tested in the field for five growing seasons to evaluate their resistance against rusts and powdery mildew. The results indicated high chitinase activity at T0 and high transgene expression levels in few transgenic families. This resulted in high resistance against wheat rusts and powdery mildew under field conditions. It was indicated by proximate and chemical analyses that one of the transgenic families and the non-transgenic line were substantially equivalent.
\end{abstract}

Conclusion: Transgenic wheat with barley chi26 was found to be resistant even after five generations under artificial fungal infection conditions. One transgenic line was proved to be substantially equivalent as compared to the nontransgenic control.

Keywords: Transgenesis, Southern, qPCR, Chitinase activity, qRT-PCR, Substantial equivalence

\footnotetext{
*Correspondence: halaeissa@yahoo.com; gamalhosman@yahoo.com; bahieldin55@gmail.com

${ }^{1}$ Agricultural Genetic Engineering Research Institute (AGERI), Agriculture Research Center (ARC), Giza 12619, Egypt

${ }^{3}$ Department of Biological Sciences, Faculty of Science, King Abdulaziz University, P.O. Box 80141, Jeddah 21589, Saudi Arabia

${ }^{10}$ Department of Biology, Faculty of Applied Sciences, Umm Al-Qura University, Makkah 21955, Saudi Arabia

Full list of author information is available at the end of the article
} 


\section{Background}

Wheat, rice, and maize are the most important food crops, as they contribute to $60 \%$ of the food consumed in the world [1]. Food security depends upon our ability to increase the production of cereals concomitant with the growing population [2]. Rust diseases, including leaf rust (Puccinia recondite Eriks), yellow or stripe rust (Puccinia striiformis Westend), and stem rust (Puccinia graminis Pers.: Pers) are the most important foliar diseases in wheat [3], causing yield losses of up to 20\% [4]. Plants respond to fungal infection by complex mechanisms. The production of pathogenesis-related (PR) proteins [5-7], such as chitinase and $\beta-1,3$-glucanase, is one of the most effective strategies involved in plant immune response [8]. Chitinase (poly[1,4-N-acetyl- $\beta$-D-glucosamine] glycan hydrolase, EC 3.2.1.14) catalyzes the hydrolysis of $\beta 1$-4-linkages of $\mathrm{N}$-acetylglucosamine of chitin resulting in $N$-acetyl glucosamine oligomers [9]. Chitin is the major component of fungal cell walls [9]; therefore, the ability of chitinase to hydrolyze fungal cell wall can be employed to inhibit the growth of fungal hyphal tips [10, 11]. Resistant wheat cultivars can be obtained via genetic transformation, and deployed to reduce yield losses and protect seed quality deteriorated by rust and powdery mildew diseases. Molecular breeding and transgenesis are two main approaches of developing disease resistant crops [12]. The expression of chitinase gene has been found to enhance the resistance against fungal diseases in many plant species via genetic transformation, for instance, the expression of a class II chitinase in Brassica juncea could successfully provide protection against Alternaria leaf spot disease [13]. A high chitinase activity along with improved $\beta-1,3$-glucanase activity in transgenic grapevines enhanced the resistance against downy mildew [14]. The introduction of rice chitinase ( $R C 7)$ in Indica rice bestowed considerable resistance against sheath blight [15]. The AFP-CHI transgenic oriental melons could resist the infection of Rhizoctonia solani and Fusarium oxysporum [16]. Earlier studies in wheat indicated that the constitutive expression of class II barley chitinase could enhance resistance against Erysiphe graminis [17] and Fusarium graminearum [18, 19]. The aim of the present work was to evaluate transgenic wheat lines, harboring the barley chi26 gene for resistance against rust and powdery mildew diseases. The T4, T5, T6, T8, and T9 generations of the four transgenic lines were assayed using artificial infection in the field over five growing seasons. The most promising transgenic family was analyzed in contrast to the non-transgenic controls to substantiate the resistance.

\section{Methods}

\section{Genetic transformation}

The plasmid pBarley/chi/bar (Fig. 1) harboring the full-length barley chi26 and bar genes [20] was used to transform immature embryos of bread wheat (Triticum aestivum L.) cv. Hi-Line. The tissue culture and transformation were carried out as reported previously by Sivamani et al. [21]. The obtained primary transformants were transferred to the biocontainment facility at Agricultural Genetic Engineering Research Institute (AGERI), Agriculture Research Center (ARC), Giza, Ministry of Agriculture, Egypt, and assayed using leaf painting with $1 \mathrm{~g} / \mathrm{L}$ of Basta ${ }^{\mathrm{TM}}$ (Bayer Crop Science PVT Ltd). Biosafety measures and guidelines were followed across the nine growing and testing seasons of the transgenic lines and their families.

\section{Polymerase chain reaction (PCR)}

Genomic DNA was extracted from putative transgenic plants, which were resistant to the herbicide Basta $^{\mathrm{TM}}$, and the non-transgenic (cv. Hi-Line) control, using the DNeasy ${ }^{\mathrm{TM}}$ Plant Mini kit (Qiagen, cat no. 69104). Using PCR, chi26 (800 bp) as well as bar (485 bp) gene

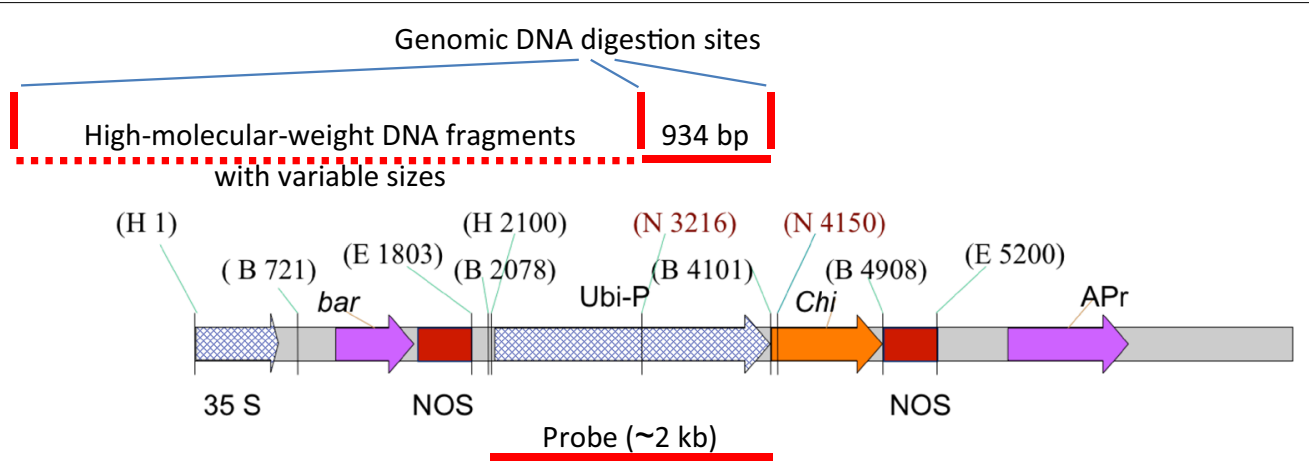

Fig. 1 Restriction map of the plant expression vector pBarley/chi/bar. H, Hindlll; B, BamHI; E, EcoRl; N, Ncol. Sites of probe and genomic DNA digestions are indicated by red solid and/or dotted lines 
fragments were amplified using gene-specific primers (Additional file 1: Table S1). The reaction conditions were optimized in a mixture (50 $\mu \mathrm{L}$ total volume) composed of dNTPs $(0.2 \mathrm{mM}), \mathrm{MgCl}_{2}(1.5 \mathrm{mM}), 1 \times$ buffer, primers $(0.2 \mu \mathrm{M})$, template DNA (100 ng), and Taq DNA polymerase (2 units). The amplification was carried out in a Hybaid PCR Express system. The system was programmed for 40 cycles as follows: $94{ }^{\circ} \mathrm{C}$ for $4 \mathrm{~min}(1$ cycle); $94{ }^{\circ} \mathrm{C}$ for $1 \mathrm{~min}, 58^{\circ} \mathrm{C}$ for $1 \mathrm{~min}$ (for chi26 gene) or $55{ }^{\circ} \mathrm{C}$ for $1 \mathrm{~min}$ (for $\mathrm{bar}$ gene), $72{ }^{\circ} \mathrm{C}$ for $2 \mathrm{~min}$ ( 38 cycles); $72{ }^{\circ} \mathrm{C}$ for $8 \mathrm{~min}(1 \mathrm{cycle}) ; 4^{\circ} \mathrm{C}$ (overnight). The amplified products were resolved on an agarose gel (1.2\%). QuickLoad 100 bp DNA ladder (New England Biolabs) was used as a DNA standard. Electrophoresis was performed at $80 \mathrm{~V}$ and DNA bands were visualized on a UV-transilluminator and documented by a digital camera.

\section{Southern blot hybridization}

Southern hybridization was performed as described by Sambrook et al. [22] using ${ }^{32} \mathrm{P}$ random labeling method for the four selected transgenic lines (CHI 7, CHI 14, CHI 47 , and $\mathrm{CHI} 71$ ) at T0 generation and for the non-transgenic parent (cv. Hi-Line). The genomic DNA of each line $(30 \mu \mathrm{g})$ was digested with $\mathrm{Nco}$ I so that a fragment of the plasmid with $934 \mathrm{bp}$, a high-molecular-weight (HMW) fragment including a portion of the plasmid, and a portion of the genomic DNA with unknown sizes based on the location of the insertion (Fig. 1) could be obtained. After this, the digested DNA preparations of different transgenic lines were analyzed by $0.8 \%$ agarose gel electrophoresis. The blot was probed with the BamHI fragment of $\mathrm{pBarley} / \mathrm{chi} / \mathrm{bar}$ containing the maize $u b i$ promoter and $u b i$ intron1 ( 2 kb) (Fig. 1).

\section{qPCR}

In order to detect chi26 gene copy number in different transgenic lines, qPCR was carried on the leaf samples of 6-week-old T0 plantlets. The following standard equation was used to determine the number of chi26 transgene copies in wheat haploid genome per microliter:

$$
\begin{aligned}
\text { No. copies (genomes } / \mu \mathrm{L})= & \frac{\text { DNA concentration }(\mathrm{g} / \mathrm{L})}{\text { Molecular weight }(\mathrm{g} / \mathrm{mol})} \\
& \times \text { Avogadro's no. } \times 10^{-6}
\end{aligned}
$$

The genomic DNA samples were serially diluted to obtain the final quantity as 186, 93 and $18.6 \mathrm{ng}$, which were equal to 10,000, 5000 and 1000 haploid genomes/ $\mu \mathrm{L}$, respectively. qPCR was performed using 1000 copy number $(18.6 \mathrm{ng})$ to be considered in the standard curve. The same quantification equation was used to generate standard curves for the absolute quantification of chi26 transgene. The pBarley/chi/bar DNA was serially diluted to obtain the final quantity as $8.6,0.86,0.086$ and $0.0086 \mathrm{ng}$, which were equal to $100,000,10,000,1000$ and 100 copies/ $\mu \mathrm{L}$, respectively. All qPCRs were performed in triplets by using the gene-specific primers. The final reaction volume was $20 \mu \mathrm{L}$ containing $1 \mu \mathrm{L}$ DNA, $10 \mu \mathrm{L}$ of $2 \times$ Fast SYBR Green Master Mix (Life technologies, USA), and $1 \mu \mathrm{L}$ of $500 \mathrm{nM}$ of each primer. The reactions were carried out on an Mx3005P qPCR System (Stratagene), employing following conditions: $10 \mathrm{~min}$ at $95{ }^{\circ} \mathrm{C}$, 40 cycles of $30 \mathrm{~s}$ at $95{ }^{\circ} \mathrm{C}, 60 \mathrm{~s}$ at $60{ }^{\circ} \mathrm{C}, 20 \mathrm{~s}$ at $72{ }^{\circ} \mathrm{C}$ and $10 \mathrm{~min}$ at $72{ }^{\circ} \mathrm{C}$. The optimal threshold lines were automatically determined by Mx3005p software (Agilent Technologies, Santa Clara, CA). The efficiencies of qPCR for each gene were determined by the following equation $\left(\mathrm{E}=\left(10^{-1 / \mathrm{m}}-1\right) \times 100\right)$ according to Radonić et al. [23], where $E$ is the PCR efficiency; $m$ is the slope of the logtransformed DNA quantities versus $\mathrm{Ct}$ values according to the equation $(\mathrm{y}(\mathrm{Ct})=\mathrm{m} \log (\mathrm{x})+\mathrm{b}(\mathrm{y}$-intercept $))$. Standard deviation (SD) and coefficient of variance (CV) were estimated in MS Excel.

\section{Chitinase enzyme assay}

Chitinase enzyme assay was performed to compare the enzyme activities in different T0 transgenic lines with that of non-transgenic parental line (cv. Hi-Line) that was recovered from tissue culture with growth conditions similar to those used to generate different transgenic lines. Total proteins were extracted from leaf tissues $(0.5 \mathrm{~g})$, and protein concentrations were measured according to Bradford method [24]. The chitinase enzyme assay is based on a colorimetric method [25] where colloidal chitin is used as a substrate. The substrate was prepared from crab shell chitin (Sigma) [26] and $\mathrm{N}$-acetylglucosamine (GlcNAc) was used as the standard. The enzyme activity is defined as $\mu \mathrm{mol}$ GlcNAc $\mathrm{min}^{-1} \mathrm{mg}^{-1}$ protein at $37^{\circ} \mathrm{C}$. Standard error (SE) was determined of three replicates using MS Excel.

\section{qRT-PCR}

Total RNA was extracted from leaf tissues of selected transgenic lines at T0 and their families using TRIZOL reagent (Invitrogen, cat. 15596-018). The extracted RNA samples were treated with DNase IRQ1 RNase-free DNase (Promega, cat. no. M6101) to remove genomic DNA contamination. The expression of the integrated transgene was tested from the extracted RNA in the T0 transgenic lines that showed positive results of Basta ${ }^{\text {TM }}$ resistance and expected PCR outcome. The expression of chi26 gene was also tested for transgenic lines for T3-T9 generations. For each sample, $2 \mu \mathrm{g}$ of total RNA was used to synthesize first strand cDNA with oligo(dT) using Revert Aid Premium Reverse Transcriptase (Thermo Scientific ${ }^{\mathrm{TM}}$ cat. no. EP0451), and chi26 
gene-specific primers (designed by GenScript Real-time PCR Primer Design, www.genscript.com/ssl-bin/app/ primer) (Additional file 2: Table S2). The templates were normalized to amplify a 196-bp fragment using actin gene primers (Additional file 2: Table S2) for the wheat actin (AY663392) gene, which was used as the internal reference qRT-PCR was done in a total volume of $25-\mu \mathrm{L}$, which contained $1 \mu \mathrm{L}$ cDNA, $12.5 \mu \mathrm{L} 2 \times$ BIO-RAD iQTMSYBR ${ }^{\circledR}$ GreenSupermix, $0.75 \mu \mathrm{L}$ ROX reference dye (1:500 diluted), and $1 \mu \mathrm{L} 500 \mathrm{nM}$ of each primer. All reactions were performed in triplicate. An Mx3005P qPCR System (Stratagene) was used with following reaction conditions: 5 min at $95^{\circ} \mathrm{C}, 40$ cycles of $30 \mathrm{~s}$ at $95^{\circ} \mathrm{C}, 60 \mathrm{~s}$ at $60{ }^{\circ} \mathrm{C}, 20 \mathrm{~s}$ at $72{ }^{\circ} \mathrm{C}$ and $10 \mathrm{~min}$ at $72{ }^{\circ} \mathrm{C}$. PCR products were examined by melt curve analysis. The actin expression level was quantified in each of the transgenic events and families as well as in the non-transgenic parents as the reference house-keeping gene. The amplicons obtained from the actin gene attained saturation between 18 and 22 cycles. The expression level of chi26 gene relative to the actin gene was calculated using MxPro QPCR Software v4.10 package, which compares reaction takeoff points (cycle number). Relative mRNA abundance in each transgenic line was compared to the non-transgenic line (cv. Hi-Line) using the comparative $C_{t}\left(2^{-\Delta \Delta C t}\right)$ method [27] with following equation: relative fold change in gene expression $=2^{-\Delta \Delta \mathrm{Ct}}$, where $\Delta \Delta \mathrm{C}_{\mathrm{t}}=\Delta \mathrm{C}_{\mathrm{t} \text { transgenic }}$ $\Delta \mathrm{C}_{\text {tnon-transgenic }}$ and $\Delta \mathrm{Ct}=\mathrm{C}_{\mathrm{t} \text { target gene }}-\mathrm{C}_{\mathrm{t} \text { reference gene }}$.

Data were statistically analyzed using the analysis of variance (ANOVA) via MSTATC program and multiple comparisons were made following Duncan's Multiple Range test [28].

\section{Field evaluation}

Five field experiments were conducted over five growing seasons (2009-2010, 2010-2011, 2011-2012, 2013-2014, and 2014-2015) to evaluate the transgenic wheat families at T4, T5, T6, T8 and T9 generations, respectively. These transgenic families harbor the barley chi26 gene conferring resistance against wheat rusts, i.e., leaf rust (Puccinia recondita), stem rust (Puccinia graminis), yellow rust (Puccinia striiformis) and powdery mildew (Blumeria graminis). The experimental field (Gemmiza Research Station, Gharbia Governorate, Egypt, Latitude $30^{\circ} 47^{\prime} 21.98^{\prime \prime}$, Longitude $31^{\circ} 7^{\prime} 33.97^{\prime \prime}$ ) was located at a place with suitable environmental conditions in terms of temperature and humidity for the infection of the fungi. The field was surrounded by a border of a mixture of highly susceptible genotypes to wheat rusts and powdery mildew, i.e., Giza 160, Morocco and Triticum spelta. At booting stage, the transgenic plants were artificially exposed to an inoculum containing the mixture of the highest virulent isolates of powdery mildew, leaf, yellow, and stem rust pathotypes [29] to ensure early epidemic by rusts. The disease severity of leaf rust was scored according to the scale described by Peterson et al. [30] (where $0=$ no infection, $R=$ resistant, $\operatorname{Tr}=$ traces, $\mathrm{MR}=$ moderately resistant, $\mathrm{MS}=$ moderately susceptible and $S=$ susceptible) with different intensities (5-100). In a similar vein, the disease severity of powdery mildew was recorded according to the scale described by Leath and Heun [31] (where $0=$ immune, no visible signs or symptoms; $1=$ highly resistant, small flecks only; $2=$ resistant, chlorotic flecks evident; $3=$ resistant, large flecks with chlorosis and necrosis; $4=$ intermediate, mycelium and conidia barely detectable; $5=$ moderately susceptible, small to moderate-sized pustules and conidia present; $6=$ moderately susceptible, predominance of moderate-sized pustules and conidia present; $7=$ susceptible, at least $50 \%$ of the leaf covered with large pustules and conidia; $8=$ susceptible, $75-80 \%$ of the leaf covered with large pustules and conidia; and $9=$ susceptible, $100 \%$ of the leaf segment covered with large pustules and conidia). A randomized complete block design with three replicates was applied for all the experiments. However, the experiments were different on the grounds of the availability of plant materials and the selection for the stable and more resistant transgenics. During the cultivation season of 2009-2010, twenty seeds each of 33 transgenic T4 families as well as the non-transgenic parental line (cv. Hi-Line) were planted in rows $(40 \mathrm{~cm}$ apart), $1 \mathrm{~m}$ each. During the cultivation season of 2010 2011, transgenic families as well as the non-transgenic cv. Hi-Line were sown in plots $(1.2 \times 3.0 \mathrm{~m})$ consisting of six rows. The seeds of selected single plants were sown in each plot in five replicates. The seeds of transgenic wheat families of subsequent generations during the following seasons were sown in plots $(20 \mathrm{~m} \times 2.4 \mathrm{~m})$ as a demonstration experiment in five replicates. The seeds were sown at the rate of $123 \mathrm{~kg} / \mathrm{Ha}$ as adopted by the National Wheat program in Egypt and all the standard agricultural practices were properly followed.

\section{In silico transgene toxicity and computational analyses}

The protein sequences of the inserted genes) i.e., chi26 and bar) in transgenic family CHI 14/6 were aligned to the toxicity database (Toxin and Toxin Target Database, T3DB, www.t3db.org) and to the structural database of allergenic proteins (SDAP, http://fermi.utmb.edu/cgi-bin/ SDAP/sdap_14). The same transgenic family was selected for compositional analysis as compared to the non-transgenic cv. Hi-Line. Other analyses were carried out at the Regional Center for Food and Feed (RCFF), Agriculture Research Center (ARC), Giza, Egypt. Proximate compositions, such as moisture, energy, crude fiber, crude protein, crude fat, and ash content, of the investigated 
whole-wheat flour samples were carried out according to the AOAC (2006). The vitamin contents were determined using HPLC (Danish Official, HPLC method No. AB 189.2 (1996), National food Agency of Denmark). The official method of analysis of AOAC International no. 969.33, Chapter 41, P. 19-20, 18th ed. (2006) was used to analyze the fatty acid compositions. The amino acid contents were analyzed using the official methods of analysis of AOAC International no. 994.12, Chapter 4, pp. 17-19, 18th Edition (2005).

\section{Results}

\section{Wheat transformation and recovery of transgenic families}

The plant expression vector pBarley/chi/bar (Fig. 1) containing the barley chi26 gene was transfected to the immature embryos of wheat cultivar Hi-Line by particle bombarding. Putative transgenics were screened using the herbicide Basta $(1 \mathrm{~g} / \mathrm{L})$. Of the 72 transgenic lines, 14 were identified and their transgenic seeds were planted individually to obtain T1 generation. An offspring generated from a seed was considered a separate transgenic family. To facilitate the tracing of the different transgenic families across generations, nomenclature starting at the T1 generation was employed by adding new number to the original T0 identifier, e.g., CHI $14 / 6$ refers to the T1 plant no. 6 generated from T1 seed no. 6 of the original transgenic line $\mathrm{CHI}$ 14. The plants obtained indifferent generations were allowed only to self pollinate.

\section{Gene expression and chitinase activity analyses}

The PCR results (Fig. 2) confirmed the presence of the full-length chi26 (800 bp) and bar (400 bp) genes in the genomic DNA of the 14 putative transgenic plants. Southern blotting was performed to confirm the integration of $\mathrm{pBarley} / \mathrm{chi} / \mathrm{bar}$ construct in the wheat genomic DNA and to detect the transgene copy number in different transgenic lines. Figure 3 shows the hybridization pattern of the generated probe with the genomic DNA of four (CHI 7, CHI 14, CHI 47, and CHI 71) out of the 14 putative transgenic lines. An expected fragment of 934 bp was detected in the genomic DNA of the transgenic lines but was completely absent in the non-transgenic line (cv. Hi-Line). Several chi-specific hybridizing HMW DNA fragments of variable length were observed indicating that the four transgenic lines independently originated from different embryogenic cells representing different integration events. In addition, the number of bands indicated different copy numbers of the transgene. Transgenic lines $\mathrm{CHI} 14$ and $\mathrm{CHI} 47$ showed the presence of a single transgene copy, while transgenic lines $\mathrm{CHI} 7$ and $\mathrm{CHI} 71$ indicated the occurrence of two transgene copies. The copy number was also confirmed
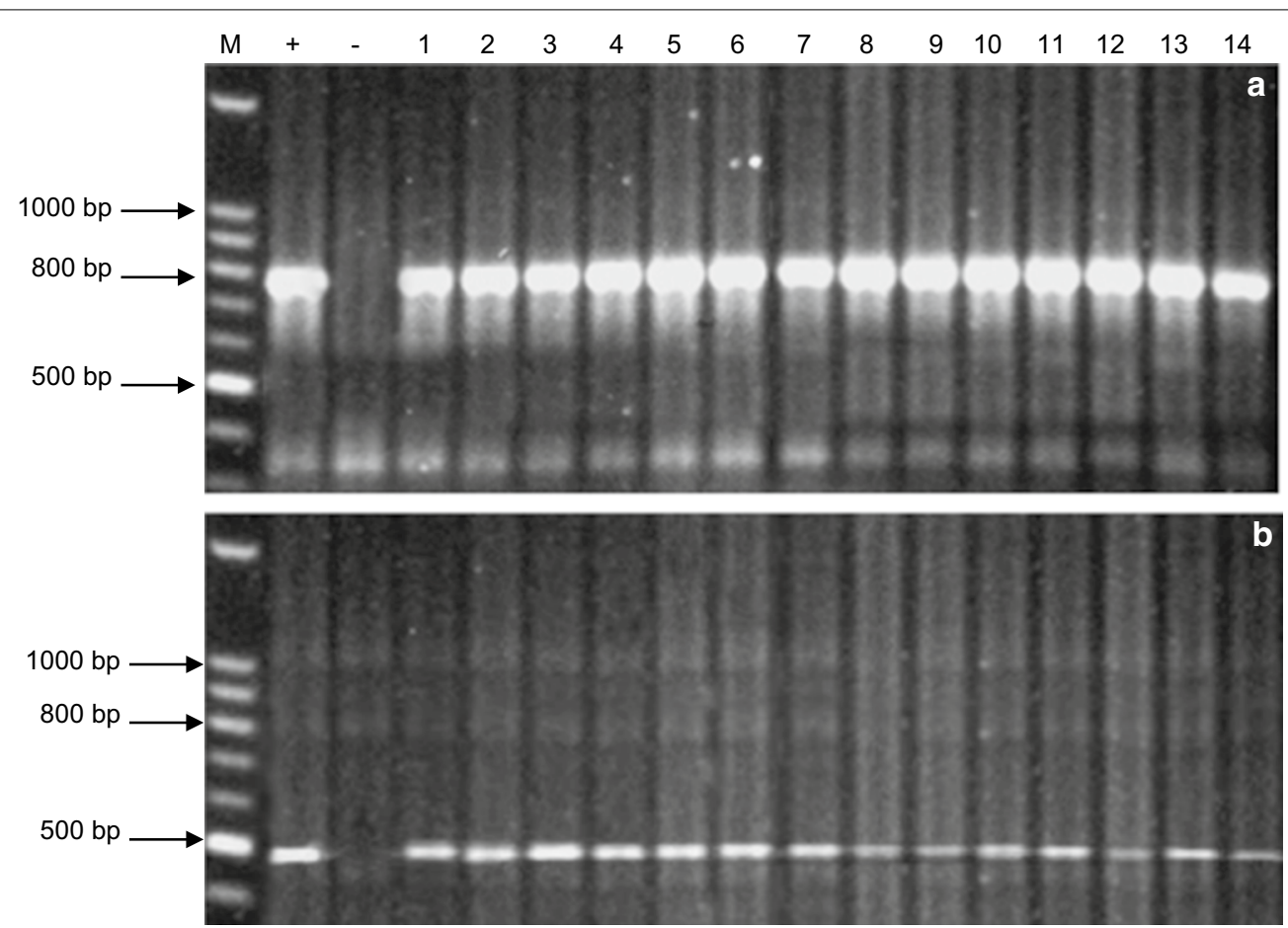

Fig. 2 PCR products of chi26 (800 bp) (a) and bar (400 bp) (b) genes from the 14 independent T0 transgenic lines (CHI 1, CHI 3, CHI 6, CHI 7, CHI 9 , $\mathrm{CHI} 10, \mathrm{CHI} 14, \mathrm{CHI} 16, \mathrm{CHI} 20, \mathrm{CHI} 22, \mathrm{CHI} 30, \mathrm{CHI} 47, \mathrm{CHI} 50$, and CHI 71, lanes 1-14, respectively). M: Quick-Load ${ }^{\circledR} 100$ bp DNA Ladder (New England Biolabs), +: positive control (pBarley/chi/bar), -: negative control (non-transgenic, cv. Hi-Line) 


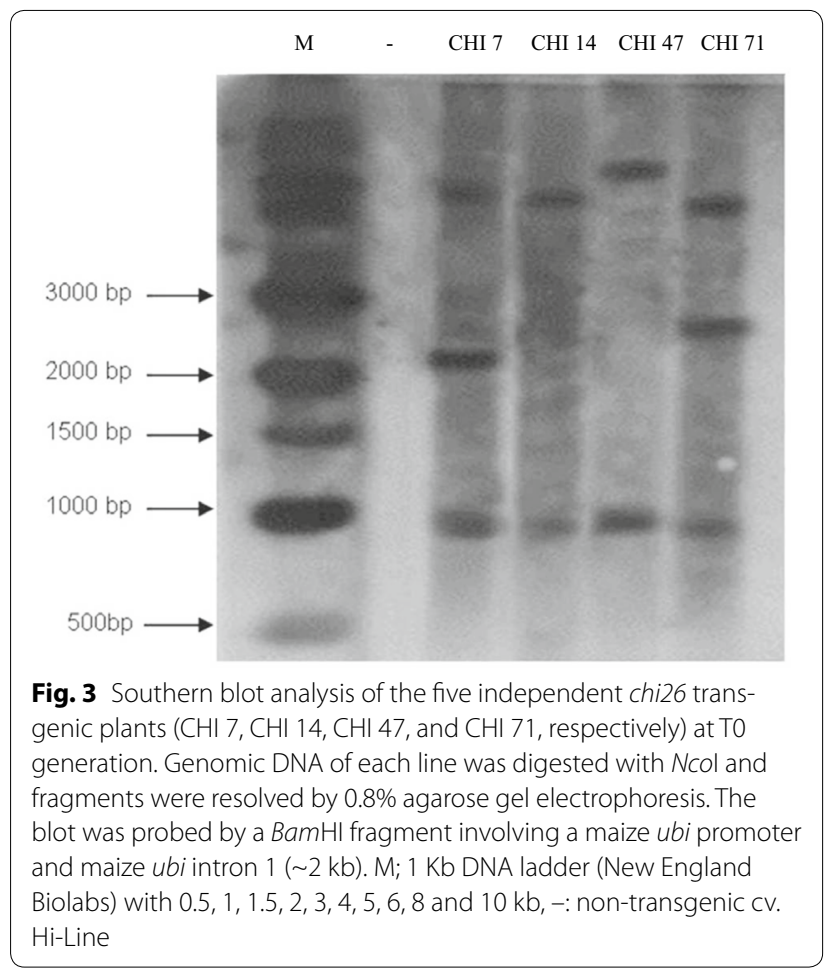

by qPCR [32] for the chi26 transcripts of the four transgenic lines at T0 generation. The mean $C_{t}$ values for all sample were obtained from three replicates considering an identical threshold. The obtained values of mean $C_{t}$, standard error (SD) and coefficient of variance $(C V)$ are listed in Table 1. The levels of actin gene expression in different transgenic lines and the non-transgenic control were identical. qRT-PCR analysis at T0 revealed different patterns for the four transgenic lines. The line $\mathrm{CHI} 14$ showed the maximum transcript abundance followed by the lines $\mathrm{CHI} 71$ and $\mathrm{CHI}$ 47, while the line CHI 7 showed the lowest value (Fig. 4). qRT-PCR for the selected families of the three transgenic lines $\mathrm{CHI}$ 14, CHI 47 and CHI 71 (i.e., CHI 14/3, CHI 14/6, CHI 14/10; CHI 14/13, CHI 47/1, CHI 47/2, CHI 47/3, CHI 71/3, CHI 71/4, CHI 71/8, CHI 71/9 and $\mathrm{CHI} 71 / 10$ ) was also carried out to detect any possibility of gene silencing in the gene families across different generations up to T9 (Fig. 5). The results indicated that chi26 gene was silenced in all transgene families in different generations, except for CHI 14/6, CHI 47/1 and CHI 71/8. The transgene in these families was not silenced across the nine studied generations. The gene silencing in the families of the transgenic line $\mathrm{CHI} 71$ took place early at T3 (i.e., CHI 71/10) and T4 (i.e., CHI 71/3, CHI 71/4 and $\mathrm{CHI} 71 / 9$ ), while it took longer and occurred at $\mathrm{T} 6$ in the families of transgenic lines CHI 14 (i.e., CHI 14/3, CHI 14/10 and CHI 14/13) and CHI 47 (i.e., families CHI $47 / 2$ and $\mathrm{CHI} 47 / 3$ ). As shown in Table 2, the chitinase activity was higher in the T0 transgenic lines than their parental non-transgenic line (Hi-Line). There were variations in enzyme activity among the tested transgenic lines. The line CHI 14 had the highest activity (15.1 U/ mg) followed by the lines CHI 47 and CHI 71 (14.3 and $12.7 \mathrm{unit} / \mathrm{mg}$, respectively). These results concord with

Table 1 Estimated chi26-transgene copy number in the T0 transgenic plants determined byqRT-PCR

\begin{tabular}{|c|c|c|c|c|}
\hline Line no. & $\begin{array}{l}\text { (Quantity) } 100 \\
\text { target copies }\end{array}$ & Copy average $\pm S D$ & $\begin{array}{l}\text { CV of copy } \\
\text { average }\end{array}$ & $\begin{array}{l}\text { Estimated } \\
\text { copy number }\end{array}$ \\
\hline \multirow[t]{3}{*}{$\mathrm{CHI} 7$} & $0.93 E+03$ & $1.27^{\mathrm{E}+03} \pm 4.81^{\mathrm{E}+02}$ & 0.38 & 2 \\
\hline & $1.28 \mathrm{E}+03$ & & & \\
\hline & $1.61 \mathrm{E}+03$ & & & \\
\hline \multirow[t]{5}{*}{$\mathrm{CHI} 14$} & $0.82 \mathrm{E}+03$ & $0.95^{\mathrm{E}+03} \pm 1.80^{\mathrm{E}+02}$ & 0.19 & 1 \\
\hline & $0.94 \mathrm{E}+03$ & & & \\
\hline & $1.08 \mathrm{E}+03$ & & & \\
\hline & $1.55 E+03$ & & & \\
\hline & $1.43 \mathrm{E}+03$ & & & \\
\hline \multirow[t]{3}{*}{$\mathrm{CHI} 47$} & $0.64 \mathrm{E}+03$ & $0.78^{\mathrm{E}+03} \pm 1.98^{\mathrm{E}+02}$ & 0.25 & 1 \\
\hline & $0.8 \mathrm{E}+03$ & & & \\
\hline & $0.90 E+03$ & & & \\
\hline \multirow[t]{3}{*}{$\mathrm{CHI} 71$} & $1.43 E+03$ & $1.45^{\mathrm{E}+03} \pm 1.56^{\mathrm{E}+02}$ & 0.11 & 2 \\
\hline & $1.35 E+03$ & & & \\
\hline & $1.57 \mathrm{E}+03$ & & & \\
\hline \multirow[t]{3}{*}{ Hi-Line (non-transgenic) } & - & - & - & - \\
\hline & - & & & \\
\hline & - & & & \\
\hline
\end{tabular}




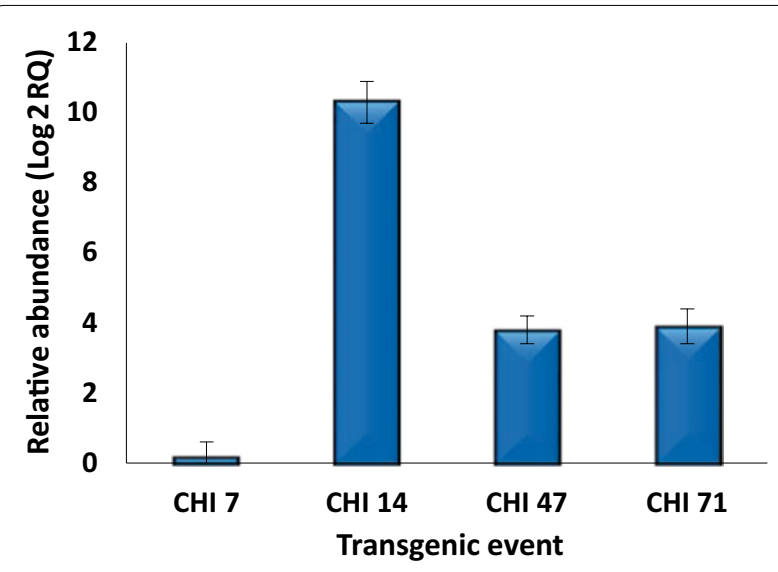

Fig. 4 qRT-PCR analysis of relative transcript abundance of chiz6 transgene in transgenic wheat lines $(\mathrm{CHI} 7, \mathrm{CHI} 14, \mathrm{CHI} 47$ and $\mathrm{CHI} 71)$ at T0 generation. Data were statistically analyzed and multiple comparisons were made following Duncan's multiple range test [28]

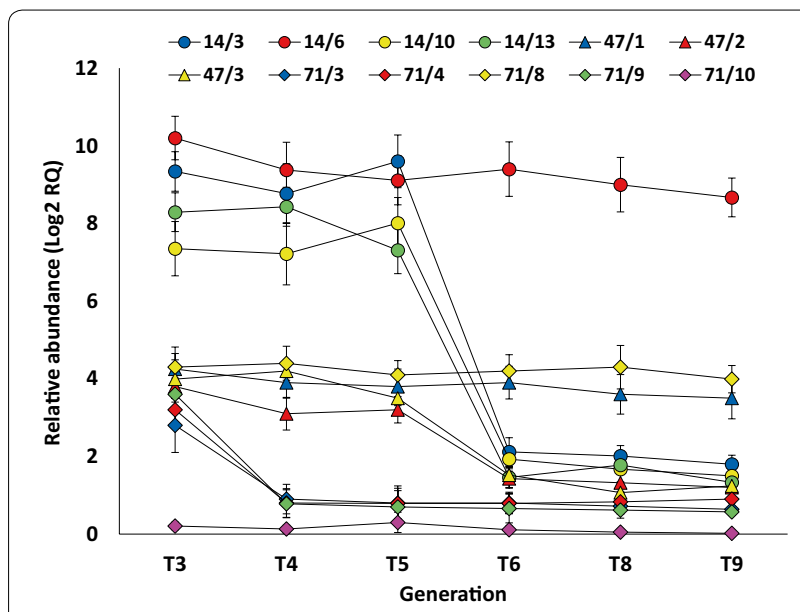

Fig. 5 qRT-PCR analysis of relative transcript abundance of chi26 transgene in T3-T9 transgenic wheat families (CHI 14/3, CHI 14/6, CHI 14/10, CHI 14/13, CHI 47/1, CHI 47/2, CHI 47/3, CHI 71/3, CHI 71/4, CHI $71 / 8, \mathrm{CHI} 71 / 9$ and $\mathrm{CHI} 71 / 10$ ) belonging to three transgenic lines $\mathrm{CHI}$ 14 (filled circles), $\mathrm{CHI} 47$ (filled triangles) and CHI 71 (filled diamonds).

Data were statistically analyzed and multiple comparisons were made following Duncan's multiple range test [28]

those of qRT-PCR for chi26 transcript abundance (Fig. 4) in different transgenic lines.

\section{Field evaluation of rusts and powdery mildew disease resistance}

The resistance of the selected transgenic wheat families against two wheat rusts, leaf rust (Puccinia recondita) and yellow rust(Puccinia strifformis), and powdery mildew (Blumeria graminis), was evaluated in five field experiments through five growing seasons (2009-2010, 2010-2011, 2011-2012, 2013-2014 and 2014-2015) at
Table 2 Mean chitinase activity in T0 transgenic wheat plants with barley chi26 gene

\begin{tabular}{lc}
\hline Transgenic line & $\begin{array}{c}\text { Mean chitinase activity } \\
\text { (U/mg of protein) } \pm \text { SE }\end{array}$ \\
\hline $\mathrm{CHI} \mathrm{7}$ & $3.7 \pm 0.5$ \\
$\mathrm{CHI} 14$ & $15.1 \pm 1.6$ \\
$\mathrm{CHI} 47$ & $14.3 \pm 0.8$ \\
$\mathrm{CHI} 71$ & $12.7 \pm 1.8$ \\
Hi-Line (non-transgenic) & $3.0 \pm 0.75$
\end{tabular}

The values are expressed as mean \pm standard error (SE) of three technical replicates

Gemmiza Research Station, Egypt. As shown in Table 3, the degree of resistance varied among the transgenic families against the combined infection of the three fungi across different seasons. In addition, the resistance level against different fungi in a given generation varied among the families of the same transgenic event. During cultivation season of 2009-2010, 25 CHI families belonging to four independent homozygous transgenic lines (CHI 7, CHI 14, CHI 47 and CHI 71) were evaluated. In this season, the environmental conditions at Gemmiza station were not suitable for the growth of yellow rust, as there were no yellow rust symptoms on the cultivars grown on the susceptible border, but the conditions were optimal for leaf rust and powdery mildew infections. All the families of transgenic line CHI 14 were considerably resistant to leaf rust and powdery mildew infections. In contrast, all the families of line CHI 7 were susceptible to the infection of leaf rust and powdery mildew; these line, therefore, were not proceeded to field testing for further generations. Three families of line 47 (CHI 47/1, $\mathrm{CHI} 47 / 2$, and CHI 47/3) and one family of line CHI 71 (CHI 71/8) were resistant to leaf rust and powdery mildew both (Table 3). The other families of the line CHI 47 were highly susceptible to the two fungi, so were excluded from field testing in further generations. The families of line CHI 71 ranged from being moderately resistant to highly susceptible to leaf rust and being susceptible to highly susceptible to powdery mildew, during this and the following four seasons. The highly susceptible family CHI 71/10 was used in field-testing for further generations, as a chi26 non-expressing transgenic family in addition to the wild type. The data recorded during the 2010-2011 season for the selected 12 transgenic families were similar to those obtained in the first season against the two fungi. The resistance levels against yellow rust were parallel to those were against leaf rust. In the season 2011-2012, high susceptibility against the three fungi started to arise in the five (CHI 14/3, CHI 14/10, CHI 14/13, CHI $47 / 2$ and $\mathrm{CHI} 47 / 3$ ) of the eight resistant families. The results obtained during the seasons 2013-2014 
Table 3 Evaluation of field data for T4, T5, T6, T8, and T9 transgenic wheat families as well as their parental non-transgenic cv. Hi-Line, for resistance against wheat rusts, leaf rust (Puccinia triticina) and yellow rust (Puccinia striiformis $f$. sp. tritici), and powdery mildew (Blumeria graminis) under artificial inoculation at the field of Gemmiza Research Station during the growing seasons 2009-2010, 2010-2011, 2011-2012, 2013-2014 and 2014-2015

\begin{tabular}{|c|c|c|c|c|c|c|c|c|c|c|c|c|c|c|c|c|}
\hline \multicolumn{2}{|l|}{ Growing season } & \multirow{2}{*}{\multicolumn{3}{|c|}{$\begin{array}{l}2009-2010 \\
\text { (T4) }\end{array}$}} & \multirow{2}{*}{\multicolumn{3}{|c|}{$\begin{array}{l}2010-2011 \\
\text { (T5) }\end{array}$}} & \multirow{2}{*}{\multicolumn{3}{|c|}{$\begin{array}{l}2011-2012 \\
\text { (T6) }\end{array}$}} & \multirow{2}{*}{\multicolumn{3}{|c|}{$\begin{array}{l}2013-2014 \\
\text { (T8) }\end{array}$}} & \multirow{2}{*}{\multicolumn{3}{|c|}{$\begin{array}{l}2014-2015 \\
\text { (T9) }\end{array}$}} \\
\hline & \multirow[t]{3}{*}{ Family no. } & & & & & & & & & & & & & & & \\
\hline \multirow[t]{2}{*}{ Transgenic line no. } & & \multicolumn{15}{|l|}{ Fungus } \\
\hline & & Lr & $\mathrm{Yr}$ & $\mathrm{Pm}$ & Lr & $\mathrm{Yr}$ & $\mathrm{Pm}$ & Lr & $\mathrm{Yr}$ & $\mathrm{Pm}$ & Lr & $\mathrm{Yr}$ & $\mathrm{Pm}$ & Lr & Yr & $\mathrm{Pm}$ \\
\hline \multirow[t]{5}{*}{7} & $7 / 4$ & 805 & NA & 8 & - & - & - & - & - & - & - & - & - & - & - & - \\
\hline & $7 / 7$ & $80 S$ & NA & 8 & - & - & - & - & - & - & - & - & - & - & - & - \\
\hline & $7 / 12$ & $80 S$ & NA & 8 & - & - & - & - & - & - & - & - & - & - & - & - \\
\hline & $7 / 30$ & 805 & NA & 8 & - & - & - & - & - & - & - & - & - & - & - & - \\
\hline & $7 / 33$ & 805 & NA & 8 & - & - & - & - & - & - & - & - & - & - & - & - \\
\hline \multirow[t]{4}{*}{14} & $14 / 3$ & $\mathrm{R}$ & NA & 0 & $\mathrm{R} / 0$ & 0 & 0 & $5 \mathrm{MR}$ & $\mathrm{MR} / \mathrm{Tr}$ & 2 & $20 \mathrm{MR}$ & $5 \mathrm{MR}$ & 2 & $20 \mathrm{MR}$ & $5 \mathrm{MR}$ & 2 \\
\hline & $14 / 6$ & 0 & NA & 0 & 0 & 0 & 0 & 0 & 0 & 0 & 0 & 0 & 0 & 0 & 0 & 0 \\
\hline & $14 / 10$ & $\mathrm{R} / 0$ & NA & 0 & $\mathrm{R} / 0$ & 0 & 0 & $30 \mathrm{MR}$ & $30 \mathrm{MR}$ & 3 & MS/MR & $20 \mathrm{MS}$ & 3 & $5 \mathrm{MS}$ & $5 \mathrm{MS}$ & 3 \\
\hline & $14 / 13$ & 0 & NA & 0 & $\mathrm{R}$ & $\mathrm{R}$ & 0 & $30 \mathrm{MR}$ & $30 \mathrm{MR}$ & 3 & $30 \mathrm{MR}$ & $20 M R$ & 3 & $30 \mathrm{MR}$ & $5 \mathrm{MR}$ & 3 \\
\hline \multirow[t]{11}{*}{47} & $47 / 1$ & $\mathrm{R}$ & NA & 0 & $\mathrm{R}$ & $\mathrm{R} / 0$ & 0 & $\mathrm{R}$ & $\mathrm{Tr} / \mathrm{R}$ & 0 & $\mathrm{R}$ & $\mathrm{Tr} / \mathrm{R}$ & 0 & $\mathrm{R} / 0$ & $\mathrm{R}$ & 0 \\
\hline & $47 / 2$ & $\mathrm{Tr} / \mathrm{R}$ & NA & 0 & $\mathrm{Tr}$ & $\mathrm{Tr} / \mathrm{R}$ & 0 & $20 \mathrm{MS}$ & MS/MR & 3 & $30 \mathrm{MS}$ & MS/MR & 3 & $20 \mathrm{MS}$ & $20 \mathrm{MS}$ & 3 \\
\hline & $47 / 3$ & $\mathrm{R}$ & NA & 0 & $\mathrm{Tr} / \mathrm{R}$ & $\mathrm{Tr}$ & 0 & MS/MR & $20 \mathrm{MS}$ & 3 & $20 \mathrm{MS}$ & $20 \mathrm{MS}$ & 3 & $30 \mathrm{MS}$ & $5 S$ & 3 \\
\hline & $47 / 5$ & 605 & NA & 8 & - & - & - & - & - & - & - & - & - & - & - & - \\
\hline & $47 / 6$ & 605 & NA & 8 & - & - & - & - & - & - & - & - & - & - & - & - \\
\hline & $47 / 7$ & 805 & NA & 8 & - & - & - & - & - & - & - & - & - & - & - & - \\
\hline & $47 / 8$ & 605 & NA & 8 & - & - & - & - & - & - & - & - & - & - & - & - \\
\hline & $47 / 9$ & 605 & NA & 8 & - & - & - & - & - & - & - & - & - & - & - & - \\
\hline & $47 / 10$ & $80 S$ & NA & 8 & - & - & - & - & - & - & - & - & - & - & - & - \\
\hline & $47 / 11$ & 605 & NA & 8 & - & - & - & - & - & - & - & - & - & - & - & - \\
\hline & $47 / 12$ & $60 S$ & NA & 8 & - & - & - & - & - & - & - & - & - & - & - & - \\
\hline \multirow[t]{5}{*}{71} & $71 / 3$ & MS/MR & NA & 6 & MS & $5 S$ & 6 & 605 & $5 S$ & 8 & 605 & $20 S$ & 8 & 605 & $20 S$ & 8 \\
\hline & $71 / 4$ & MS & NA & 6 & $20 \mathrm{~S}$ & $20 \mathrm{MR}$ & 6 & $60 \mathrm{~S}$ & $30 \mathrm{MS}$ & 6 & 605 & $30 \mathrm{MS}$ & 6 & $60 \mathrm{~S}$ & $30 S$ & 8 \\
\hline & $71 / 8$ & $\mathrm{R}$ & NA & 0 & $\mathrm{R}$ & $\operatorname{Tr}$ & 0 & $\mathrm{R} / 0$ & $\mathrm{Tr} / \mathrm{R}$ & 0 & $\mathrm{Tr} / \mathrm{R}$ & $\mathrm{R}$ & 0 & R & $\mathrm{R} / 0$ & 0 \\
\hline & $71 / 9$ & $30 S$ & NA & 6 & $60 \mathrm{~S}$ & MS/MR & 6 & $80 \mathrm{~S}$ & MS & 6 & $80 S$ & $5 S$ & 8 & $80-5$ & $20 \mathrm{~S}$ & 8 \\
\hline & $71 / 10$ & $80 S$ & NA & 8 & $80 \mathrm{~S}$ & $60 \mathrm{~S}$ & 8 & $80 \mathrm{~S}$ & $80 S$ & 8 & $80 S$ & $80 S$ & 8 & $80 S$ & 805 & 8 \\
\hline Hi-Line & & $80 S$ & NA & 9 & $80 \mathrm{~S}$ & 805 & 9 & $80-5$ & $80 S$ & 9 & $80-5$ & $80 S$ & 9 & $80-5$ & $80 S$ & 9 \\
\hline
\end{tabular}

$L r$ leaf rust, $Y r$ yellow rust, $P m$ powdery mildew. $0(\mathrm{Lr}$ and $\mathrm{Yr}$ ) $=$ no infection, $\mathrm{R}=$ resistant, $\mathrm{Tr}=$ traces, $\mathrm{MR}=$ moderate resistant, $\mathrm{MS}=\mathrm{moderate}$ susceptible and $\mathrm{S}=$ susceptible. $\mathrm{NA}=$ not applicable. $0(\mathrm{Pm})=$ immune, no visible signs or symptoms; $1=$ highly resistant, smallflecks only; $2=$ resistant, chlorotic flecks evident; $3=$ resistant, large flecks with chlorosis and necrosis; $4=$ intermediate, mycelium and conidia barely detectable; $5=$ moderately susceptible, small to moderate-sized pustules and conidia present; $6=$ moderately susceptible, predominance of moderate-sized pustules and conidia present; $7=$ susceptible, at least $50 \%$ of the leaf covered with large pustules and conidia; $8=$ susceptible, $75-80 \%$ of the leaf covered with large pustules and conidia; and $9=$ susceptible

and 2014-2015 for the 12 families were almost similar to those obtained during 2011-2012 for the selected 12 families. The results for the season $2009-2010$ indicated that selective transgene silencing occurred in earlier generations for the family lines, $\mathrm{CHI} 7$ and $\mathrm{CHI} 71$, but excepting $\mathrm{CHI} 71 / 8$. The results obtained during the season 2014-2015 and two following growing seasons indicated possible occurrence of gene silencing in the families of the lines $\mathrm{CHI} 14$ and $\mathrm{CHI} 47$, except CHI $14 / 6$ and $\mathrm{CHI} 47 / 1$. The performance of chi26-expressing transgenic line (e.g., CHI 14/6) versus non-transgenic line under combined infection is shown in Fig. 6. This observation is also supported by a video captured at the field station during the last season to indicate the performance of the co-existing transgenic and non-transgenic plants during the season 2014-2015 (Additional file 3: Movie 1). Regarding stem rust (Puccinia graminis), the parental cultivar Hi-Line was natively resistant to the pathotypes available at the research station. Therefore, the effect of chi26 gene towards stem rust resistance could not be evaluated through the field experiments carried out. The data presented in Table 3 for the field experiments 


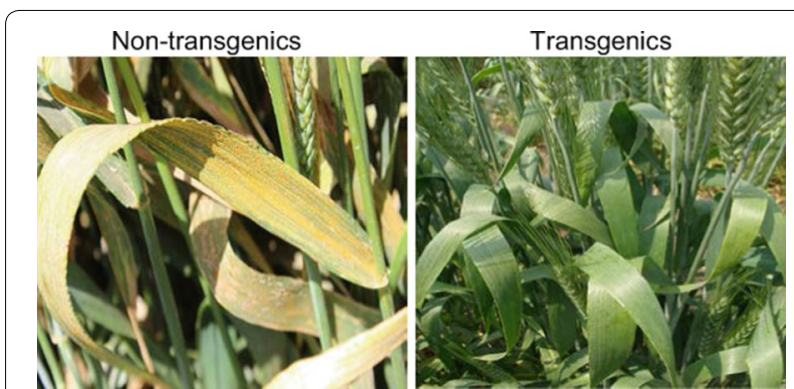

Fig. 6 Comparison between chi26-transgenic (CHI 14/6) and nontransgenic wheat plants grown at the field station during the season 2014-2015 indicating the combined effects of the three fungi: powdery mildew, and leaf and yellow rusts

concurred well with those obtained by qRT-PCR, in terms of gene expression levels of different transgenic families across generations (Fig. 5). As a result, the transgenic family CHI 14/6 was selected for further testing of possible transgene toxicity and substantial equivalence.

\section{In silico analysis of possible transgene toxicity and substantial equivalence testing}

The protein sequences of the inserted genes (chi and bar) were aligned to the toxicity (Toxin and Toxin Target Database, T3DB, www.t3db.org) and allergenicity (SDAP, http://fermi.utmb.edu/cgi-bin/SDAP/sdap_14) databases, and no homology was observed between the proteins encoded by both the genes and any known toxic compound. The deduced amino acid sequence of the protein encoded by bar gene showed no homology with any known allergen. However, there was some homology ( $\sim 35 \%)$ between the deduced amino acid sequence of the protein encoded by chi26 gene and an allergen protein in banana. Phenotypic changes, in terms of the performance of the transgenic plants, were observed across the different seasons in comparison to their parental non-transgenic plants following the guidelines of the European Food Safety Authority (EFSA) for genetically modified organisms. The results indicated that there were no observable phenotypic differences within transgenics and between the transgenics and non-transgenic parental plants. The overall mode of reproduction and the survivability rate of the transgenic plants were the same as to the non-transgenics. The proximate analysis and compositions of vitamins, fatty acids, and amino acids of CHI 14/6 transgenic family were similar to those of the parental Hi-Line (Table 4). The chi26-transgenic family showed a slight increase in protein and fat contents compared to the wild type, and slightly lower levels of vitamins B1 and B2 and fatty acids, except linolenic acid. The amino acid profiles were not affected by the presence of the transgene.

\section{Discussion}

In many countries, wheat serves as an important staple crop. Depending on the climatic conditions, it can be infested by a wide variety of fungi [33]. The conventional method to control fungal parasites is mainly dependent on the extensive use of chemical fungicides, which are harmful to the ecological system, leave considerable residual toxicity to humans and animals, and increase the production cost. Moreover, fungi have developed resistance to some of the available commercial fungicides [34]. Therefore, it is desirable to develop resistant cultivars by the introduction of resistance genes employing conventional breeding and genetic transformation. Chitinase is one of the defense genes that can abort fungal growth by degrading the chitin of growing hyphae by chitinase [35]. Several studies have demonstrated that enhanced chitinase levels in transgenic plants can increase the plant resistance against several fungal pathogens. The plants tested for this approach are rice [15], ryegrass [36], tomato [37], peanut [38], banana [39], finger millet [40], and melon [16]. The first attempt to produce transgenic wheat with chitinase gene dates back to 1998, which was unsuccessful due to the silencing and loss of chitinase expression in T1 and subsequent generations [41]. Bliffeld et al. [17] generated transgenic wheat plants constitutively expressing antifungal barley-seed class II chitinase. The transfected plants were able to reduce the severity of the infection by Erysiphe graminis in transgenic wheat plants. Another study achieved the same results [42], wherein the number of the spore-containing colonies was reduced on the leaves of barley class II chitinase transgenic wheat lines (30-50\%) at an inoculum density of approximately 100 mildew (Erysiphe graminis) or 80 rust (Puccinia recondita) spores per $\mathrm{cm}^{2}$. The evaluation of transgenic lines overproducing chitinase and $\beta-1,3-$ glucanase showed resistance to Fusarium graminearum in greenhouse conditions. However, the same lines failed to show any resistance under actual field conditions [43]. On the other hand, Shin et al. [19] generated seven transgenic wheat lines expressing the barley class II chitinase. These lines exhibited high Type II Fusarium head blight (FHB) resistance in the greenhouse and two of them also showed enhanced resistance even in the field.

In this study, we inserted the barley chi26 coding cDNA into the wheat genome (cv. Hi-Line) via biolistic bombardment. The gene integration in the transgenic plants was confirmed by the Southern blotting and the gene expression was confirmed by qRT-PCR and chitinase activity assays. To the best of our knowledge, the present study is the first in evaluating chitinase-expressing transgenic wheat in natural field conditions for five seasons at a hot spot region (Gemmiza Research Station, Gharbia Governorate, Egypt) suitable for testing wheat rusts and powdery 
Table 4 Comparison between proximate analysis, and vitamin, fatty acid and amino acid contents of CHI 14/6 and nontransgenic cv. Hi-Line

\begin{tabular}{|c|c|c|c|c|c|}
\hline & Hi-Line & $\mathrm{CHI} 14 / 6$ & & Hi-Line & CHI14/6 \\
\hline Proximate analysis (\%) & & & Vitamins (mg/kg) & & \\
\hline Moisture & $10.40^{*}$ & 10.40 & Vit B1 & $5.100^{\mathrm{A}}$ & $5.000^{A}$ \\
\hline Ash & 1.37 & 1.72 & Vit B2 (mg/kg) & $0.539^{\mathrm{A}}$ & $0.480^{A}$ \\
\hline Crude fiber & 2.71 & 2.6 & Para-aminobenzoic acid & $770.000^{A}$ & $800.000^{A}$ \\
\hline Crude protein & 15.4 & 15.6 & & & \\
\hline Crude fat & 2.16 & 2.25 & & & \\
\hline Fatty acids (\%) & & & Amino acids (\%) & & \\
\hline Caprylic acid & 0.2 & - & Alanine & $0.51^{\mathrm{A}}$ & $0.56^{\mathrm{A}}$ \\
\hline Capric acid & 0.2 & - & Arginine & $0.77^{\mathrm{A}}$ & $0.72^{\mathrm{A}}$ \\
\hline Myristic acid & 0.1 & - & Aspartic acid & $0.83^{\mathrm{A}}$ & $0.76^{A}$ \\
\hline Palmitic acid & 21.7 & 17.2 & Glutamic acid & $4.15^{\mathrm{A}}$ & $4.25^{\mathrm{A}}$ \\
\hline Palmitoleic acid & 0.6 & - & Glycine & $0.63^{\mathrm{A}}$ & $0.73^{\mathrm{A}}$ \\
\hline Stearic acid & 2.9 & 2 & Histidine & $0.34^{\mathrm{A}}$ & $0.33^{\mathrm{A}}$ \\
\hline Oleic acid & 17.6 & 16.2 & Isoleucine & $0.49^{A}$ & $0.45^{\mathrm{A}}$ \\
\hline Vaccenic acid & 1.2 & 1 & Leucine & $0.96^{\mathrm{A}}$ & $0.91^{\mathrm{A}}$ \\
\hline Linoleic acid & 51 & 60.7 & Lysine & $0.39^{A}$ & $0.38^{\mathrm{A}}$ \\
\hline Linolenic acid & 3.2 & 2.9 & Phenylalanine & $0.66^{\mathrm{A}}$ & $0.66^{\mathrm{A}}$ \\
\hline Gadoleic acid & 0.6 & 0.7 & Proline & $3.73^{\mathrm{A}}$ & $1.33^{\mathrm{A}}$ \\
\hline Arachidic acid & - & 0.1 & Serine & $0.63^{\mathrm{A}}$ & $0.57^{\mathrm{A}}$ \\
\hline$C 20: 1 \omega 7$ & 0.4 & - & Threonine & $0.42^{\mathrm{A}}$ & $0.38^{\mathrm{A}}$ \\
\hline \multirow[t]{2}{*}{ Non identified fatty acid } & 0.3 & 0.2 & Tyrosine & $0.49^{A}$ & $0.48^{\mathrm{A}}$ \\
\hline & & & Valine & $0.62^{\mathrm{A}}$ & $0.65^{\mathrm{A}}$ \\
\hline
\end{tabular}

* Data of three biological replicates were statistically analyzed and multiple comparisons were made following Duncan's Multiple Range test [28]. Numbers in the same row followed by the same letter are not significantly different

mildew. According to the field data obtained, it can be concluded that some transgenic wheat families with chi26 gene showed high resistance to rust diseases, including leaf rust (Puccinia recondita), yellow rust (Puccinia striiformis) and powdery mildew (Blumeria graminis) (Table 3). There were some variations in the resistance in the field among the families of the same transgenic event in a given season (Table 3). This behavior could also be supported by the data of the transgene expression level obtained by qRT-PCR for different families across different seasons (Fig. 5). The results indicated that transcription of chi26 was silenced in several families at T3, T4, and T6 generations. This conclusion is supported by the data generated during fieldtesting. Stability in transgene expression was observed at T7 up to T9. The phenomenon of gene silencing has also been reported earlier [41], where the authors found that the majority of the $\mathrm{T} 1$ progeny showed very limited or almost no chitinase gene expression despite carrying an intact transgene. They ascribed this behavior to the use of CaMV-35S promoter driving the transgene. Transgene silencing has also been reported by other investigators [44, 45], with this as well other promoters, e.g., CaMV-35S [45, 46], Act1D [44], and maize ubi1 [43, 47], with different transformation methods, such as Agrobacterium-mediated transformation of oilseed rape $[48,49]$ and microprojectile bombardment for wheat $[43,47]$. These reports and the current study support the conclusion that transgene silencing is not correlated to any specific promoter or transformation method used. The high frequency of gene silencing might occur via homology-dependent silencing [50], tandem insertions, or genomic DNA could be interspersed between transgenic sequences [51-53]. Another explanation is the occurrence of promoter methylation, where expression level can be largely linked to the degree of promoter methylation $[43,47]$. The results of the current study are in agreement with the latter possibility because we found fluctuations in chi26 expression in subsequent generations for families generated from the same transgenic event. In addition, we observed no direct correlation between the transgene copy number and the silencing level, where $\mathrm{CHI} 14$ and $\mathrm{CHI} 47$ were found to have one transgene copy, while CHI 71 was having two. Similarly, Rooke et al. [54] found no correlation between the expression of the HMW glutenin subunit gene and its copy number. Despite the occurrence of transgene silencing, there was an overall stability in the degree of resistance in a given transgenic event across all tested generations (Table 3). If a given transgenic line could escape silencing 
up to T6 generation, then it is highly possible that the subsequent generations will exhibit stable expression levels. Transgene silencing in wheat is a random process and has no correlation with promoter, transgene copy number, or even position effect [43]. However, further investigation is indispensable to understand the mechanism of transgene silencing. In accordance to the possible correlation between chitinase activity and fungal disease resistance, several studies have claimed that transgenic plants with higher levels of chitinase transcript accumulation show higher levels of disease resistance and chitinase activity [36]. On the other hand, some studies carried out in rice, tobacco, and cotton, have reported that the level of chitinase activity does not always correlate with the degree of fungal resistance $[55,56]$. More recently, a simple method namely WAC, based upon the specific binding of the plant lectin wheat germ agglutinin to fungal chitin, was used to detect disease resistance against Puccinia graminis f. sp. Tritici [57]. World Health Organization (WHO), Food and Agriculture Organization (FAO), and Organization for Economic Cooperation and Development (OECD) follow the principle of the "substantial equivalence" for genetically modified food safety assessment [49]. In the current study, a comparative analysis between chi26 transgenic line and its parental non-transgenic genotype (cv. Hi-Line) was performed. None of the transgenic plants exhibited any morphological change as compared to the non-transgenic parental genotype. They were self-fertile and had normal seed setting. In addition, no significant differences in agronomic traits between the transgenic and non-transgenic families were observed under normal conditions (Additional file 4: Table S3). One of the transgenic families (CHI 14/6) showed stable resistance across the studied generations, and consequently, was chosen for subsequent proximate and nutritional analyses(Additional file 5: Figure S1). Moisture content is one of the most important considerations while evaluating the quality of wheat for long terms to rage and milling quality of the grain [48]. The moisture content in the commercial lots of wheat ranges between 8 and $18 \%$, depending on the prevalent weather at the time of harvest $[57,58]$. The moisture content of CHI14/6 and Hi-Line was the same (Table 4). In addition, the ash, protein, and fat percentages were also similar. The slight variation in fatty acid and amino acid profiles is within naturally occurring variability range and thus acceptable [49].

\section{Conclusion}

Our results indicate that the resistance against wheat rusts and powdery mildew can be achieved via transgenesis with the use of the barley chi26 gene. The recovered transgenic family CHI $14 / 6$ can be utilized in breeding programs towards the production of wheat cultivars resistant to rusts and powdery mildew.

\section{Additional files}

Additional file 1: Table S1. Specific primers to amplify chi26 and bar genes.

Additional file 2: Table S2. Specific primers to amplify chi26 and actin genes for $\mathrm{qPCR}$.

Additional file 3: Movie 1. The performances of chi26 transgenics versus non-transgenics under combined infection with rusts and powdery mildew.

Additional file 4: Table S3. Means of yield related traits of the T4 transgenic families as well as their parental non-transgenic genotype (cV Hi-Line) under field conditions in cultivated seasons 2009/2010.

Additional file 5: Fig. S1. Whole figure for Genomic Southern blot analysis of the five independent chi26 transgenic plants $\mathrm{CHI} 7, \mathrm{CHI} 30, \mathrm{CHI}$ 14, $\mathrm{CHI} 47$ and $\mathrm{CHI} 71$, respectively) at the T0 generation. Genomic DNA of each line was digested with $\mathrm{Ncol}$ and fragmented by $0.8 \%$ agarose ge electrophoresis. The blot was probed with a BamHI fragment involving a maize ubi promoter and maize ubi intron $1(\sim 2 \mathrm{~kb}) . \mathrm{M} ; 1 \mathrm{~Kb}$ DNA ladder (New England Biolabs) with 0.5, 1, 1.5, 2, 3, 4, 5, 6, 8 and 10 kb, -; nontransgenic cv. Hi-Line.

\section{Abbreviations}

G168: Giza 168; ELISA: enzyme linked-immunosorbent assay.

\section{Authors' contributions}

HFE AB: Designed the study. AMR and HTM: Constructed the vector. HFE, AMR, SHE and OMS: Carried out wheat transformation. SMH, MTA and YBM: Carried out PCR and RT-PCR. AMS: Determined chitinase activity. HAF: Carried out Southern blotting. HFE, MME, MM and GGE: Carried out field evaluation and data collection. HFE, GHO, AB, MM and AMR: Drafted the manuscript. All authors read and approved the final manuscript.

\section{Author details}

${ }^{1}$ Agricultural Genetic Engineering Research Institute (AGERI), Agriculture Research Center (ARC), Giza 12619, Egypt. ${ }^{2}$ Faculty of Biotechnology, Misr University for Science and Technology (MUST), Post Box 77, 6th October City, Egypt. ${ }^{3}$ Department of Biological Sciences, Faculty of Science, King Abdulaziz University, P.O. Box 80141, Jeddah 21589, Saudi Arabia. ${ }^{4}$ Plant Pathology Research Institute (PPRI), Agriculture Research Center (ARC), Giza 12619, Egypt. ${ }^{5}$ National Centre for Radiation Research and Technology (NCRRT), Cairo 11781, Egypt. ${ }^{6}$ Department of Biotechnology, Faculty of Applied Medical Science, Taif University, Turrabah 21995, Saudi Arabia. ${ }^{7}$ Field Crops Research Institute, Agriculture Research Center (ARC), Giza 12619, Egypt. ${ }^{8}$ Plant Soil and Microbial Sciences Department, Michigan State University, East Lansing, MI 48824, USA. ${ }^{9}$ Department of Genetics, Faculty of Agriculture, Ain Shams University, Cairo 11566, Egypt. ${ }^{10}$ Department of Biology, Faculty of Applied Sciences, Umm Al-Qura University, Makkah 21955, Saudi Arabia. ${ }^{11}$ Department of Pomology, The Horticulture Research Institute (HRI), Agriculture Research Center (ARC), Giza 12619, Egypt. ${ }^{12}$ Arid Lands Agricultural Research Institute (ALARI), Faculty of Agriculture, Ain Shams University, P.O. Box 68, Hadayek Shoubra, Cairo 11241, Egypt.

\section{Acknowledgements}

We are grateful to Prof. Dr. Subbaratnam Muthukrishnan, Kansas State University, USA for revising and editing the manuscript and making valuable suggestions.

\section{Competing interests}

The authors declare that they have no competing interests.

Availability of data and materials

All data generated or analyzed during this study are included in this published article.

\section{Funding}

This project was funded by the Science and Technology Development Fund (STDF), Ministry for Scientific Research, Egypt, under Grant No. (265). 


\section{Publisher's Note}

Springer Nature remains neutral with regard to jurisdictional claims in published maps and institutional affiliations.

Received: 5 November 2016 Accepted: 15 May 2017

Published online: 22 May 2017

\section{References}

1. Todorovska E, Christova N, Slavova S, Christovaa P, Vassileva D. Biotic stress resistance in wheat: breeding and genomic selection implications. Biotechnol Biotechnol Equip. 2009;23:1417-26.

2. Muthukrishnan S, Liang GH, Trick HN, Gill BS. Pathogenesis-related proteins and their genes in cereals. Plant Cell Tissue Organ Cult. 2001;64:93-114.

3. Hulbert SH, Bai J, Fellers JP, Pacheco MG, Bowden RL. Gene expression patterns in near isogenic lines for wheat rust resistance gene Ir34/yr18. Phytopathology. 2007;97:1083-93.

4. Oerke EC, Dehne HW. Global crop production and the efficacy of crop protection: current situation and future trends. Eur J Plant Pathol. 1997; 103:203-15.

5. Linthorst HJM, Van Loon LC. Pathogenesis-related proteins of plants. Crit Rev Plant Sci. 1991;10:123-50.

6. Colditz F, Niehaus K, Krajinski F. Silencing of PR-10-like proteins in Medicago truncatula results in an antagonistic induction of other PR proteins and in an increased tolerance upon infection with the oomycete Aphanomyces euteiches. Planta. 2007;226:57-71.

7. Choi DS, Hwang IS, Hwang BK. Requirement of the cytosolic interaction between pathogenesis-related protein 10 and leucine-rich repeat protein 1 for cell death and defense signaling in pepper. Plant Cell. 2012;24:1675-90

8. Saito S, Odagiri M, Furuya S, Suzuki S, Takayanagi T. Inhibitory effect of chitinases isolated from Semillon grapes (Vitis vinifera) on growth of grapevine pathogens. J Plant Biochem Biotechnol. 2011;20:47-54.

9. Mauch F, Mauch-Mani B, Boller T. Antifungal hydrolyses in Pea tissue 1. Plant Physiol. 1988;88:936-42

10. Adams DJ. Fungal cell wall chitinases and glucanases. Microbiology. 2004;150:2029-35.

11. Schlumbaum A, Mauch F, Vögeli U, Boller T. Plant chitinases are potent inhibitors of fungal growth. Nature. 1986;324:365-7.

12. Kaur J, Sagaram US, Shah D. Can plant defensins be used to engineer durable commercially useful fungal resistance in crop plants? Fungal Biol Rev. 2011;25:128-35.

13. Chhikara S, Chaudhury D, Dhankher OP, Jaiwal PK. Combined expression of a barley class II chitinase and type I ribosome inactivating protein in transgenic Brassica juncea provides protection against Alternaria brassicae. Plant Cell Tissue Organ Cult. 2012;108:83-9.

14. Nookaraju A, Agrawal DC. Enhanced tolerance of transgenic grapevines expressing chitinase and $\beta$-1,3-glucanase genes to downy mildew. Plant Cell Tissue Organ Cult. 2012;111:15-28.

15. Datta K, Tu J, Oliva N, Ona I, Velazhahan R, Mew TW, Muthukrishnan S, Datta SK. Enhanced resistance to sheath blight by constitutive expression of infection-related rice chitinase in transgenic elite indica rice cultivars. Plant Sci. 2001;160:405-14.

16. Bezirganoglu I, Hwang SY, Fang TJ, Shaw JF. Transgenic lines of melon (Cucumismelo L. var. makuwa cv. "Silver Light") expressing antifungal protein and chitinase genes exhibit enhanced resistance to fungal pathogens. Plant Cell Tissue Organ Cult. 2013;112:227-37.

17. Bliffeld M, Mundy J, Potrykus I, Fütterer J. Genetic engineering of wheat for increased resistance to powdery mildew disease. Theor Appl Genet. 1999;98:1079-86.

18. Anand A, Trick HN, Gill BS, Muthukrishnan S. Stable transgene expression and random gene silencing in wheat. Plant Biotechnol J. 2003;1:241-51.

19. Shin S, Mackintosh CA, Lewis J, Heinen SJ, Radmer L, Dill-Macky R, Baldridge GD, Zeyen RJ, Muehlbauer GJ. Transgenic wheat expressing a barley class II chitinase gene has enhanced resistance against Fusarium graminearum. J Exp Bot. 2008;59:2371-8.

20. Hassanein SE, Abdel-Tawab FM, Fahmy EM, Gad El-Karim G, Alniemi T, Abdelsalam M, Mostafa S, Ramadan AM, Saleh OM, Eissa HF, Bahieldin A.
Molecular assessment of chitinase activity in transgenic wheat, Egypt. J Genet Cytol. 2009;38:207-20.

21. Sivamani E, Bahieldin A, Wraith JM, Al-Niemi T, Dyer WE, Ho TD, Qu R. Improved biomass productivity and water use efficiency under water deficit conditions in transgenic wheat constitutively expressing the barley HVA1 gene. Plant Sci. 2000;155:1-9.

22. Sambrook J, Fritsch EF, Maniatis T. Molecular cloning: a laboratory manual. Cold Spring Harbor: Cold Spring Harbor Laboratory Press; 1989.

23. Radonić A, Thulke S, Mackay IM, Landt O, Siegert W, Nitsche A. Guideline to reference gene selection for quantitative real-time PCR. Biochem Biophys Res Commun. 2004;313:856-62.

24. Bradford MM. A rapid and sensitive method for the quantitation of microgram quantities of protein utilizing the principle of protein-dye binding. Anal Biochem. 1976;72:248-54.

25. Reissig JL, Strominger JL, Leloir LF. A modified colorimetric method for the estimation of $\mathrm{N}$-acetylamino sugars. J Biol Chem. 1955;217:959-66.

26. Hsu SC, Lockwood JL. Powdered chitin agar as a selective medium for enumeration of actinomycetes in water and soil. Appl Microbiol. 1975;29:422-6.

27. Livak KJ, Schmittgen TD. Analysis of relative gene expression data using realtime quantitative PCR and the 2- $\triangle \triangle C T$ method. Methods. 2001;25:402-8.

28. Duncan DB. Multiple range and multiple F-tests. Biometrics. 1955;11:1-42.

29. Tervet I, Cassel RC. The use of cyclone in the race identification of microscopic particles. Phytopathology. 1951;41:282-5.

30. Peterson RF, Campbell AB, Hannah AE. A diagrammatic scale for estimating rust intensity on leaves and stems of cereals. Can J Res. 1948;26C:496-500

31. Leath $\mathrm{S}$, Heun M. Identification of powdery mildew resistance genes in cultivars of soft red winter-wheat. Plant Dis. 1990;74:747-52.

32. Rutledge RG, Côté $C$. Mathematics of quantitative kinetic $P C R$ and the application of standard curves. Nucleic Acids Res. 2003;31:e93.

33. Roelfs AP. Estimated losses caused by rust in small grain cereals in the United States 1918-1976, Publ. United States. Agric Res Serv. 1978;1363:1-85.

34. Avila-Adame C, Olayo G, Wolfram K. Characterization of Colletotrichum graminicola isolates resistant to atrobilurin-related Qol fungicides. Plant Dis. 2003;87:1426-32.

35. Leah R, Tommerup H, Svendsen I, Mundy J. Biochemical and molecular characterization of three barley seed proteins with antifungal properties. J Biol Chem. 1991;266:1564-73.

36. Takahashi W, Fujimori M, Miura Y, Komatsu T, Nishizawa Y, Hibi T, Takamizo $T$. Increased resistance to crown rust disease in transgenic Italian ryegrass (Lolium multiflorum Lam.) expressing the rice chitinase gene. Plant Cell Rep. 2005;23:811-8.

37. Girhepuje PV, Shinde GB. Transgenic tomato plants expressing a wheat endochitinase gene demonstrate enhanced resistance to Fusarium oxysporum f. sp. lycopersici. Plant Cell Tissue Organ Cult. 2011;105:243-51.

38. Iqbal MM, Nazir F, Ali S, Asif MA, Zafar Y, labal J, Ali GM. Over expression of rice chitinase gene in transgenic peanut (Arachis hypogaea L.) improves resistance against leaf spot. Mol Biotechnol. 2012;50:129-36.

39. Kovács G, Sági L, Jacon G, Arinaitwe G, Busogoro JP, Thiry E, Strosse H, Swennen R, Remy S. Expression of a rice chitinase gene in transgenic banana ("Gros Michel", AAA genome group) confers resistance to black leaf streak disease. Transgenic Res. 2013;22:117-30.

40. Ignacimuthu S, Ceasar SA. Development of transgenic finger millet (Eleusine coracana (L.) Gaertn.) resistant to leaf blast disease. J Biosci. 2012;37:135-47.

41. Chen WP, Gu X, Liang GH, Muthukrishnan S, Chen PD, Liu DJ, Gill BS. Introduction and constitutive expression of a rice chitinase gene in bread wheat using biolistic bombardment and the bar gene as a selectable marker. Theor Appl Genet. 1998;97:1296-306.

42. Oldach KH, Becker D, Lörz H. Heterologous expression of genes mediating enhanced fungal resistance in transgenic wheat. Molecular Plant Microbe Interactions. 2001;14:832-8.

43. Anand A, Zhou T, Trick HN, Gill BS, Bockus WW, Muthukrishnan S. Greenhouse and field testing of transgenic wheat plants stably expressing genes for thaumatin-like protein, chitinase and glucanase against Fusarium graminearum. J Exp Bot. 2003;54:1101-11.

44. Demeke T, Hucl P, Båga M, Caswell K, Leung N, Chibbar RN. Transgene inheritance and silencing in hexaploid spring wheat. Theor Appl Genet. 1999;99:947-53. 
45. Melander M, Kamnert I, Happstadius I, Liljeroth E, Bryngelsson T. Stability of transgene integration and expression in subsequent generations of doubled haploid oilseed rape transformed with chitinase and $\beta-1,3$-glucanase genes in a double-gene construct. Plant Cell Rep. 2006;25:942-52.

46. Tang J, Scarth R, Mcvetty PBE. Stability of the expression of Acyl-ACP thioesterase transgenes in oilseed rape doubled haploid lines. Crop Sci. 2004;44:732-40.

47. Howarth JR, Jacquet JN, Doherty A, Jones HD, Cannell ME. Molecular genetic analysis of silencing in two lines of Triticum aestivum transformed with the reporter gene construct pAHC25. Ann Appl Biol. 2005;146:311-20.

48. Rasper VF, Walker CE. Quality evaluation of cereals and cereal products. In: Hulp K, Ponte JG, editors. Handbook of cereal science and technology. New York: Marcel Deker Inc.; 2000. p. 505-37.

49. Venneria E, Fanasca S, Monastra G, Finotti E, Ambra R, Azzini E, Durazzo A, Foddai MS, Maiani G. Assessment of the nutritional values of genetically modified wheat, corn, and tomato crops. J Agric Food Chem. 2008;56:9206-14.

50. Meyer P, Saedler H. Homology-dependent gene silencing in plants. Annu Rev Plant Physiol Plant Mol Biol. 1996;47:23-48.

51. Kohli A, Leech M, Vain P, Laurie DA, Christou P. Transgene organization in rice engineered through direct DNA transfer supports a two-phase integration mechanism mediated by the establishment of integration hot spots. Proc Natl Acad Sci USA. 1998;95:7203-8.

52. Salomon S, Puchta H. Capture of genomic and T-DNA sequences during double-strand break repair in somatic plant cells. EMBO J. 1998;17:6086-95.

53. Jackson SA, Zhang P, Chen WP, Phillips RL, Friebe B, Muthukrishnan S, Gill BS. High-resolution structural analysis of biolistic transgene integration into the genome of wheat. Theor Appl Genet. 2001;103:56-62.

54. Rooke L, Steele S, Barcelo P, Shewry PR, Lazzeri PA. Transgene inheritance, segregation and expression in bread wheat. Euphytica. 2003;129:301-9.

55. Nishizawa Y, Nishio Z, Nakazono K, Soma M, Nakajima E, Ugaki M, Hibi T. Enhanced resistance to blast (Magnaporthe grisea) in transgenic Japonica rice by constitutive expression of rice chitinase. Theor Appl Genet. 1999;99:383-90.

56. Emani C, Garcia JM, Lopata-Finch E, Pozo MJ, Uribe P, Kim DJ, Sunikumar G, Cook DR, Kenerley CM, Rathore KS. Enhanced fungal resistance in transgenic cotton expressing an endochitinase gene from Trichoderma virens. Plant Biotech J. 2003:1:321-36.

57. Ayliffe M, Periyannan SK, Feechan A, Dry I, Schumann U, Lagudah E, Pryor A. Simple quantification of in planta fungal biomass. Methods Mol Biol. 2014;1127:159-72.

58. Belderock B. Development in bread making processing. Plant Food Hum Nutr. 2000;55:1-8

\section{Submit your next manuscript to BioMed Central and we will help you at every step:}

- We accept pre-submission inquiries

- Our selector tool helps you to find the most relevant journal

- We provide round the clock customer support

- Convenient online submission

- Thorough peer review

- Inclusion in PubMed and all major indexing services

- Maximum visibility for your research

Submit your manuscript at www.biomedcentral com/submit 